\title{
Hydrogen Storage in the Carbon Dioxide - Formic Acid Cycle
}

\author{
Cornel Fink, Mickael Montandon-Clerc, and Gabor Laurenczy*
}

\begin{abstract}
This year Mankind will release about 39 Gt carbon dioxide into the earth's atmosphere, where it acts as a greenhouse gas. The chemical transformation of carbon dioxide into useful products becomes increasingly important, as the $\mathrm{CO}_{2}$ concentration in the atmosphere has reached $400 \mathrm{ppm}$. One approach to contribute to the decrease of this hazardous emission is to recycle $\mathrm{CO}_{2}$, for example reducing it to formic acid. The hydrogenation of $\mathrm{CO}_{2}$ can be achieved with a series of catalysts under basic and acidic conditions, in wide variety of solvents. To realize a hydrogen-based charge-discharge device ('hydrogen battery'), one also needs efficient catalysts for the reverse reaction, the dehydrogenation of formic acid. Despite of the fact that the overwhelming majority of these reactions are carried out using precious metals-based catalysts (mainly Ru), we review here developments for catalytic hydrogen evolution from formic acid with iron-based complexes.
\end{abstract}

Keywords: Aqueous solution · Carbon dioxide · Fe · Formic acid · Homogeneous catalysis · Hydrogen storage - Phosphine ligands $\cdot \mathrm{Ru}$

\section{$\mathrm{CO}_{2} / \mathrm{HCO}_{3}^{-} / \mathrm{CO}_{3}{ }^{2-}$ hydrogenation}

Atmospheric carbon dioxide $\left(\mathrm{CO}_{2}\right)$ is an almost infinite source of carbon and if utilized as a $\mathrm{C}_{1}$ building block, countless feed stock chemicals and compounds could be synthesized. ${ }^{[1]}$ Despite its obviously huge potential for the chemical industry, it is not a widespread exploited resource. Several reasons account for this situation such as difficulties to capture $\mathrm{CO}_{2}$ with economic efficiency from air (approximately 400 ppm). A currently more promising method seems to be to capture carbon dioxide at the source (e.g. power plants) and process the off-gas for further applications. ${ }^{[2]}$ The high thermodynamic stability of the $\mathrm{CO}_{2}$ $\left(\Delta \mathrm{H}^{\circ}=-393.5 \mathrm{~kJ} / \mathrm{mol}\right)^{[3]}$ is another challenge. ${ }^{[4]}$ Nature managed to process carbon dioxide as the sole carbon source for all plant life by mastering sunlight-driven photosynthesis, ${ }^{[5]}$ a brilliant concept which inspires scientists to mimic the procedure for hydrogen production and storage. ${ }^{[6]}$

${ }^{*}$ Correspondence: Prof. Dr. G. Laurenczy Institut des Sciences et Ingénierie Chimiques Ecole polytechnique Fédérale de Lausanne (EPFL) $\mathrm{CH}-1015$ Lausanne, Switzerland E-mail: gabor.laurenczy@epfl.ch
An alternative approach for the reduction of carbon dioxide, besides electrochemical or photochemical reduction, is via a catalytic reaction, to hydrogenate $\mathrm{CO}_{2}$ to form formic acid $(\mathrm{HCOOH})$, methanol $\left(\mathrm{H}_{3} \mathrm{COH}\right)$ or methane $\left(\mathrm{CH}_{4}\right)$. Various metals, ranging from precious rare elements such as ruthenium, rhodium, palladium, iridium or osmium down to abundant bulk metals (iron, cobalt, copper), in combination with countless different ligands have been screened towards their ability to hydrogenate carbon dioxide. Although $\mathrm{Ru}(\mathrm{II})$ complexes with phosphine ligands are predominant for this task, the number of other successfully tested metal complexes such as iron-based Fe(II)-tris[2diphenylphosphino)-ethyl]phosphine $\left(\mathrm{PP}_{3}\right)$ is steadily increasing. ${ }^{[7]}$ The applied reaction conditions are as diverse as the catalysts. Nonetheless, in all - except one $^{[8]}$ - cases, the reductions were carried out under basic conditions, which rather frames bicarbonate $\left(\mathrm{HCO}_{3}^{-}\right)$or carbonate $\left(\mathrm{CO}_{3}{ }^{2-}\right)$ the substrate than $\mathrm{CO}_{2} \cdot{ }^{[9]} \mathrm{High}$ hydrogen- and carbon dioxide pressures shift the equilibria towards formic acid formation, while increased temperatures accelerate the reaction rate, but exhibit an detrimental effect on the absolute yield since the hydrogenation of bicarbonate is an exothermic process $\left(\Delta \mathrm{G}^{\circ}=-35.4 \mathrm{~kJ} /\right.$ $\mathrm{mol} ; \Delta \mathrm{H}^{\circ}{ }_{298}=-59.8 \mathrm{~kJ} / \mathrm{mol} ; \Delta \mathrm{S}^{\circ} 298=-81$ $\mathrm{J} / \mathrm{mol}^{* \mathrm{~K})}$. $^{298}$

The reduction of carbon dioxide with heterogeneous and homogeneous catalysts has been under investigation for many decades. A milestone in $\mathrm{CO}_{2}$ fixation with heterogeneous catalysts was achieved by the Nobel Prize laureate Sabatier in the 1910 s by reducing $\mathrm{CO}_{2}$ directly to methane
(Sabatier process). For practical reasons, the focus in the further course of this review article will be on homogeneous catalysis, bearing the advantage that homogeneous catalytic processes can be studied on a molecular level more straightforwardly, which is relevant for mechanistic studies and the fine tuning of the catalysts allows better selectivity. Successful homogeneous catalytic hydrogenations of bicarbonate with homogenous catalysts have been reported as early as from the beginning of the last century. ${ }^{[11]}$ More recent publications from the 1970s describe already more advanced systems, which produced esters (HCOOEt), ${ }^{[12]}$ and upon hydrolysis $\mathrm{HCOOH}$, whereas others formed formate directly in the presence of triethylamine (basic conditions) and catalytically active transition metal complexes $\left(\mathrm{p}\left(\mathrm{H}_{2}\right) / \mathrm{p}\left(\mathrm{CO}_{2}\right)\right.$ $=1: 1,50$ bar, RT). ${ }^{[13]}$ Leitner et al. reported on a homogeneous catalyst, formed in situ from $\left[\{\mathrm{Rh}(\mathrm{cod}) \mathrm{Cl}\}_{2}\right]$ and $\mathrm{Ph}_{2} \mathrm{P}\left(\mathrm{CH}_{2}\right)_{4} \mathrm{PPh}_{2}$, which produced up to 1150 moles formate per mole rhodium. ${ }^{[14]}$ In 2010, Nozaki presented an Ir-trihydride-pincer complex, which achieved an astonishing TON (turn over number) up to 3500000 (after $48 \mathrm{~h}$ reaction time) and TOF (turnover frequency) of $150000 \mathrm{~h}^{-1}{ }^{.}{ }^{[15]}$ The latest developments in the field are neatly summarized in several recent reviews. ${ }^{[16]}$

Important research on the formation of methanol from $\mathrm{CO}_{2}$ and the reverse reaction, liberation of hydrogen, was done by the Milstein group and numerous highimpact publications give proof of their excellent work. ${ }^{[17]}$ Another approach, based on a three-step cascade synthesis, was reported by the Sanford group. ${ }^{[18]}$ To produce methanol, three different homogeneous 
catalysts transform carbon dioxide successively to methanol via reduction of $\mathrm{CO}_{2}$ to formic acid, then esterification (formate ester) and finally hydrogenation of the ester to obtain free methanol (Fig. 1). ${ }^{[18]}$ While the first two steps are well present in literature, the final hydrogenation is an innovative feature of their work.

Formic acid has an advantage over methanol and methane in terms of hydrogen storage efficiency since no water as co-product is formed during the reduction process (starting from $\mathrm{CO}_{2}$ ), which consumes valuable hydrogen equivalents (Fig. 2). Accordingly, formic acid (or more precisely the formate salts) is a promising candidate for constructing a "hydrogen battery', where the energy is stored as reversibly bound hydrogen. [19]

In 2000, we reported on the watersoluble tertiary phosphine ruthenium(II) complex, $\left[\mathrm{RuCl}_{2}(\mathrm{PTA})_{4}\right](\mathrm{PTA}=1,3,5$-triaza-7-phosphaadamantane), as a precatalyst which is capable of hydrogenating bicarbonate $\left(\mathrm{HCO}_{3}^{-}\right)$in aqueous solution and does not depend on amines or other additives. ${ }^{[20]}$ The hydride species, which was observed at $60 \mathrm{bar} \mathrm{H}_{2}$ in acidic aqueous solution, is $\left[\mathrm{RuH}_{2}\left(\mathrm{PTA}_{4}\right)_{4}\right](\mathrm{pH}=$ 2.0) while $\left[\mathrm{RuH}(\mathrm{PTA})_{4} \mathrm{Cl}\right]$ was detected in basic media $(\mathrm{pH}=12)$. Moreover, the turnover frequency of the catalyst depends strongly on the $\mathrm{pH}$. An initial TOF of $800 \mathrm{~h}^{-1}$ was measured in a 9:1 $\mathrm{CO}_{2} / \mathrm{HCO}_{3}-$ mixture $(\mathrm{pH}=5.86)$, whereas a reduced reaction rate was observed in very basic solutions (substrate $\mathrm{Na}_{2} \mathrm{CO}_{3}$ ). More detailed investigations on the active species suggested that $\mathrm{HCO}_{3}^{-}$is the primary substrate, which was confirmed later. ${ }^{[21]}$ The observed induction period at the beginning of the catalytic cycle could originate from the slow formation of the catalytically active species. Furthermore, studies on water-soluble rhodium(I) complexes with meta-monosulfonated triphenylphosphine ( $m$ TPPMS) ligands confirmed the $\mathrm{pH}$ dependency of hydride species. It was shown that the $\mathrm{pH}$ change caused by $\mathrm{CO}$ treatment in aqueous solution affects the distribution of catalytically relevant hydrido species. ${ }^{[22]} m$ TPPMS was further examined in combination with $\mathrm{Ru}(\mathrm{II})$, where the dimeric $\left[\left\{\operatorname{RuCl}\left(\mu^{2}-\mathrm{Cl}\right)(m \mathrm{TPPMS})\right\}_{2}\right] \mathrm{com}-$ plex was identified as a suitable precatalyst for bicarbonate hydrogenation, yielding HCOONa under mild conditions $\left(50{ }^{\circ} \mathrm{C}\right.$, $\mathrm{P}\left(\mathrm{H}_{2}\right)=10$ bar; Fig. 3). ${ }^{[23]}$ The reaction did not require amine additives, nonetheless the reaction rate was considerably higher after the addition of quinolone. The proposed reaction mechanism involves Ru(II)hydride species with the generalized formula $\left[\mathrm{RuHX}(m \mathrm{TPPMS})_{4}\right]$ and $\mathrm{HCO}_{3}^{-}$as substrate, where $\mathrm{X}$ represents $\mathrm{H}^{-}, \mathrm{HCO}_{3}^{-}$ or the product $\mathrm{HCOO}^{-}$. Under harsher conditions, at $80^{\circ} \mathrm{C}$ and 95 bar, previously

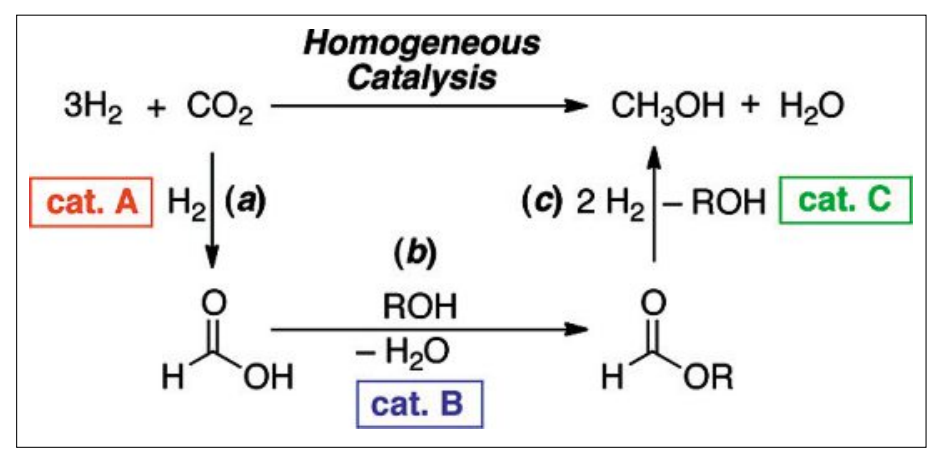

Fig. 1. Proposed cascade for the conversion of carbon dioxide and hydrogen to methanol and water. Reprinted from ref. [18] with permission from Journal of the American Chemical Society.

\begin{tabular}{|c|c|c|c|}
\hline & & $\begin{array}{c}\text { Energy content } \\
{[\mathrm{MJ} / \mathrm{kg}]}\end{array}$ & $\begin{array}{c}\text { Storage efficiency } \\
{[\%]}\end{array}$ \\
\hline $\mathrm{H}_{2}+\mathrm{CO}_{2}$ & $\Longrightarrow \mathrm{HCO}_{2} \mathrm{H}$ & 5.22 & 100 \\
\hline $3 \mathrm{H}_{2}+\mathrm{CO}_{2}$ & $\Longrightarrow \mathrm{CH}_{3} \mathrm{OH}+\mathrm{H}_{2} \mathrm{O}$ & 15.2 & 66.7 \\
\hline $4 \mathrm{H}_{2}+\mathrm{CO}_{2}$ & $\Longrightarrow \mathrm{CH}_{4}+2 \mathrm{H}_{2} \mathrm{O}$ & 30.15 & 50 \\
\hline
\end{tabular}

Fig. 2. $\mathrm{CO}_{2}$ hydrogenation in respect to consumed $\mathrm{H}_{2}$ equivalents.

unreached high TOFs of $9600 \mathrm{~h}^{-1}$ for water-soluble Ru(II) phosphine complexes in aqueous solution were measured.

Another class of catalytically active complexes are the $\mathrm{Ru}(\mathrm{II})$ arene compounds with the general formula [ $\eta^{6}$-arene $) \mathrm{Ru}(\mathrm{II})$ $\mathrm{Cl}_{2}$ (PTA)]. ${ }^{[24]}$ These complexes can exchange one or both $\mathrm{Cl}^{-}$for hydrides, forming $\left[\left(\eta^{6}\right.\right.$-arene $\left.) \mathrm{Ru}(\mathrm{II}) \mathrm{H}(\mathrm{PTA}) \mathrm{Cl}\right]$ and $\left[\left(\eta^{6}\right.\right.$ arene) $\left.\mathrm{Ru}(\mathrm{II}) \mathrm{H}_{2}(\mathrm{PTA})\right]$. Besides the ability to hydrogenate bicarbonate, an interesting dynamic behavior of the compounds was noticed. During prolonged hydrogenation at elevated temperatures, an excess of PTA leads to the loss of the arene group, and the resultant complexes show catalytic activity for hydrogenation of $\mathrm{HCO}_{3}^{-}$. Identified species were [RuH(PTA $\left.)_{4} \mathrm{Cl}\right]$, $\left[\mathrm{RuH}(\mathrm{PTA})_{4} \mathrm{H}_{2} \mathrm{O}\right]^{+}, \quad\left[\mathrm{RuH}_{2}(\mathrm{PTA})_{4}\right]$ and $\left[\mathrm{RuH}(\mathrm{PTA})_{5}\right]^{+}$. At the end of the experiment, the in situ formed catalyst reached almost full conversion of bicarbonate. Interestingly, no initial induction period was observed as described for the direct application of $\left[\mathrm{RuCl}_{2}(\mathrm{PTA})_{4}\right]$ catalysts. ${ }^{20]}$
Later, a series of imidazolium-tethered ruthenium(II)-arene complexes was synthesized and their application for catalysis was subsequently assessed.[25] Dimeric $\mathrm{Ru}(\mathrm{II})$ salts with the general structure $\left[\left\{\mathrm{RuCl}\left(\mu^{2}-\mathrm{Cl}\right)(\eta 6 \text {-arene })\right\}_{2}\right]$ were treated with phosphine ligands $\left(\mathrm{PPh}_{3}, \mathrm{PCy}_{3}\right)$ which lead to catalyst precursors. These complexes were active in aqueous solution on the reduction of bicarbonate and carbonate. High-pressure NMR measurements allowed the identification of a bicarbonatehydride intermediate.

A similar group of compounds was scrutinized in 2007.[26] There, the watersoluble Ru(II) complexes [Cp'RuX(PTA) $\mathrm{Y}$ and $\left[\mathrm{CpRuCl}\left(\mathrm{PPh}_{3}\right)(\mathrm{mPTA})\right] \mathrm{OTf}\left(\mathrm{Cp}^{\prime}=\right.$ $\mathrm{Cp}, \mathrm{Cp}^{*}$ - (1,2,3,4,5-pentamethylcyclopentadienyl), $\mathrm{X}=\mathrm{Cl}$ and $\mathrm{Y}=$ nil; or $\mathrm{X}=$ $\mathrm{MeCN}$ and $\mathrm{Y}=\mathrm{PF}_{6}$; mPTA $=1$-methyl1,3,5-triaza-7-phosphaadamantane) acted as precatalysts in the hydrogenation of $\mathrm{HCO}_{3}^{-}$and $\mathrm{CO}_{2}$ in amine- and additivefree aqueous solution under reasonable conditions $\left(30-80{ }^{\circ} \mathrm{C}, \mathrm{p}\left(\mathrm{H}_{2}\right)=100\right.$ bar $)$.

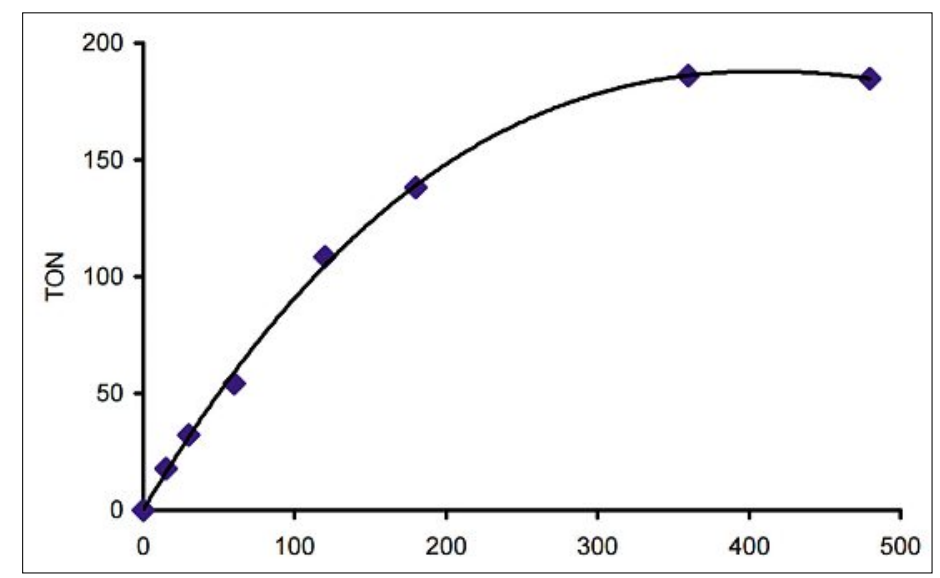

Fig. 3. Time course of $\mathrm{HCO}_{3}{ }^{-}$reduction by [\{RuCl $\left.\left.(\mathrm{mTPPMS})_{2}\right\}_{2}\right]$ and mTPPMS; final concentration of sodium formate did not exceed the initial bicarbonate concentration; no other products were detected. Reprinted from ref. [23] with permission from Applied Catalysis A: General. 
The activities are described as moderate for bicarbonate hydrogenation.

A NMR study confirmed in 2007 the existence of a previously proposed intermediate in the catalytic hydrogenation of carbon dioxide/bicarbonate in aqueous media. ${ }^{[21]}$ The water soluble $\mathrm{Ru}(\mathrm{II})$ precatalyst with the structure $\left[\mathrm{RuCl}_{2}(\mathrm{PTA})\left([9] \mathrm{aneS}_{3}\right)\right]$ ([9]ane $\mathrm{S}_{3}=1,4,7$-trithiacyclononane) has low catalytic activity for the hydrogenation of bicarbonate but allowed the identification of an important intermediate by ${ }^{1} \mathrm{H}$, ${ }^{13} \mathrm{C}$, and ${ }^{31} \mathrm{P}$ NMR spectroscopy, where a hydride and a bicarbonate are coordinated to the $\mathrm{Ru}$ center. Accordingly, the in situ observed catalytically active species can be described as $\left[\mathrm{Ru}(\mathrm{H})\left(\mathrm{CO}_{3} \mathrm{H}\right)(\mathrm{PTA})([9]\right.$ aneS $_{3}$ )] (Fig. 4). [21] The reduction of carbon dioxide takes place via bicarbonate hydrogenation and the rate-limiting step seems to be the intramolecular transfer of hydrides on the substrate.

Beside ruthenium(II) complexes, iridium(III) complexes showed comparable catalytic activity in aqueous phase carbon dioxide $\left(\mathrm{HCO}_{3}^{-}\right)$hydrogenation. ${ }^{[27]}$ We investigated two water-soluble iridium complexes, $\left[\mathrm{Cp} * \operatorname{Ir}(\mathrm{PTA}) \mathrm{Cl}_{2}\right]$ and $\left[\mathrm{Cp} * \operatorname{Ir}(\mathrm{PTA})_{2} \mathrm{Cl}\right] \mathrm{Cl}$, as catalyst precursors. The monophosphine compound performed poorly while the bisphosphine precatalyst demonstrated moderate activity for bicarbonate hydrogenation. Furthermore, the catalysts were fully characterized (solution and solid state, Fig. 5) ${ }^{[27]}$ and the catalytically active species $\left[\mathrm{Cp}^{*} \operatorname{IrH}(\mathrm{PTA})\right]^{+}$was identified by multi-nuclear NMR studies and independent synthesis. Optimal conditions for the hydrogenation were found at higher temperatures and a slightly basic $\mathrm{pH}$ of 9.

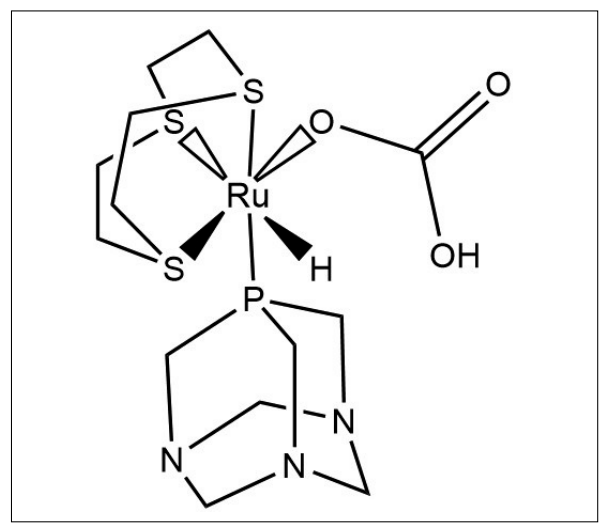

Fig. 4. Catalytic Ru(II) complex with coordinated substrate $\left(\mathrm{HCO}_{3}^{-}\right)$and hydride. Reprinted from ref. [21] with permission from Inorganic Chemistry Communications.

We patented in 2013 and published in 2014 the first and currently unique direct hydrogenation of $\mathrm{CO}_{2}$ to formic acid without any additives or amines, working in acidic aqueous solution. ${ }^{[8]}$ There, we reported on the highly active precatalyst

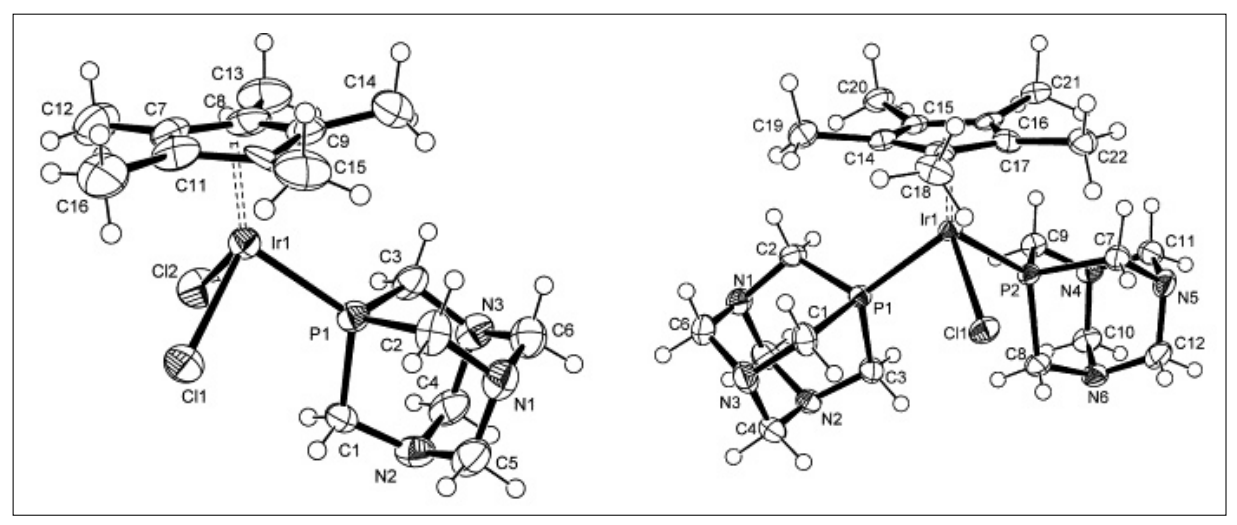

Fig. 5. ORTEP diagram of $\left[\mathrm{Cp}{ }^{\star} \operatorname{Ir}(\mathrm{PTA}) \mathrm{Cl}_{2}\right]$ and $\left[\mathrm{Cp}{ }^{*} \operatorname{Ir}(\mathrm{PTA})_{2} \mathrm{Cl}\right] \mathrm{Cl}$ with solvates; anions omitted for clarity; shown with $50 \%$ probability ellipsoids. Reprinted from ref. [27] with permission from European Journal of Inorganic Chemistry.

$\left[\mathrm{RuCl}_{2}(\mathrm{PTA})_{4}\right]$, which afforded $0.2 \mathrm{M} \mathrm{FA}$ aqueous solutions at $40{ }^{\circ} \mathrm{C}$ and 200 bar $\left(\mathrm{p}\left(\mathrm{H}_{2}\right): \mathrm{p}\left(\mathrm{CO}_{2}\right)=3: 1\right)$, however the same compound achieved excellent $1.9 \mathrm{M}$ formic acid in DMSO $\left(\mathrm{p}\left(\mathrm{H}_{2}\right) / \mathrm{p}\left(\mathrm{CO}_{2}\right)=1: 1\right.$, 100 bar, $50{ }^{\circ} \mathrm{C}$ (Fig. 6), in $\mathrm{D}_{2} \mathrm{O}, \mathrm{H}-\mathrm{D}$ exchange in formic acid). ${ }^{[28]}$ The high stability of the catalyst allowed multiple recycling without detectable decreases in activity in both reaction media. Moreover, the catalyst exclusively produces formic acid and the final $\mathrm{pH}$ was measured as 2.70 , proving the robustness of the catalyst in an acidic environment.

It was only in 2010 when, in collaboration with Beller's group, a homogeneous iron catalyst for bicarbonate hydrogenation was discovered. ${ }^{[7]}$ Different iron-containing precursors and numerous phosphineand nitrogen-containing ligands were studied. An excellent catalyst, $\mathrm{Fe}\left(\mathrm{BF}_{4}\right)_{2} / \mathrm{PP}_{3}$ $\left(\mathrm{PP}_{3}=\operatorname{tris}[2\right.$ (diphenylphosphino)ethyl] phosphine), which forms in situ, was identified, hydrogenations proceed smoothly with low catalyst loadings of $0.14 \mathrm{~mol} \%$ at $80{ }^{\circ} \mathrm{C}$. $\mathrm{NaOOCH}$ was produced in $88 \%$ yield with a turnover number of 610 , the suggested catalytic cycle is shown in Fig. 7.[7] The active species were identified by multi-nuclear NMR spectroscopy and an X-ray crystal structure of the initial $\left[\mathrm{FeH}\left(\mathrm{PP}_{3}\right)\right]$ was obtained.

The catalyst was tested on other substrates, verifying that amides and esters are also accessible by hydrogenating $\mathrm{CO}_{2}$. Methyl formate was produced in good yield $(56 \%)$ and a maximum TON of 585 was accomplished - two times higher than the best previously reported iron catalysts. In addition, dimethylformamide was formed in high yield (75\%) with a TON of 727, which was previously only known from precious metal systems (Ru, Ir, or $\mathrm{Rh}$ ), and $\mathrm{N}$-formylpiperidine was obtained in $41 \%$ yield $($ TON $=373$ ). Ethyl or propyl formate esters were formed as well, the yields and TONs were lower compared to those of methanol $(\mathrm{MeOH})$ based systems. It was known from earlier publications that the presence of base is crucial for favorable thermodynamics. [29]

Later in 2012, a new generation of ironbased catalysts was presented.[30] The addition of fluorotris-2-(diphenylphosphino) phenyl)phosphine iron(II) tetrafluoroborate to a methanolic bicarbonate solution afforded high $\mathrm{TONs}_{20 \mathrm{~h}}>7500$ and $\mathrm{TOFs}_{5 \mathrm{~h}}$ $>750\left(100^{\circ} \mathrm{C} ; \mathrm{p}\left(\mathrm{H}_{2}\right)=60\right.$ bar; $0.005 \mathrm{mmol}$

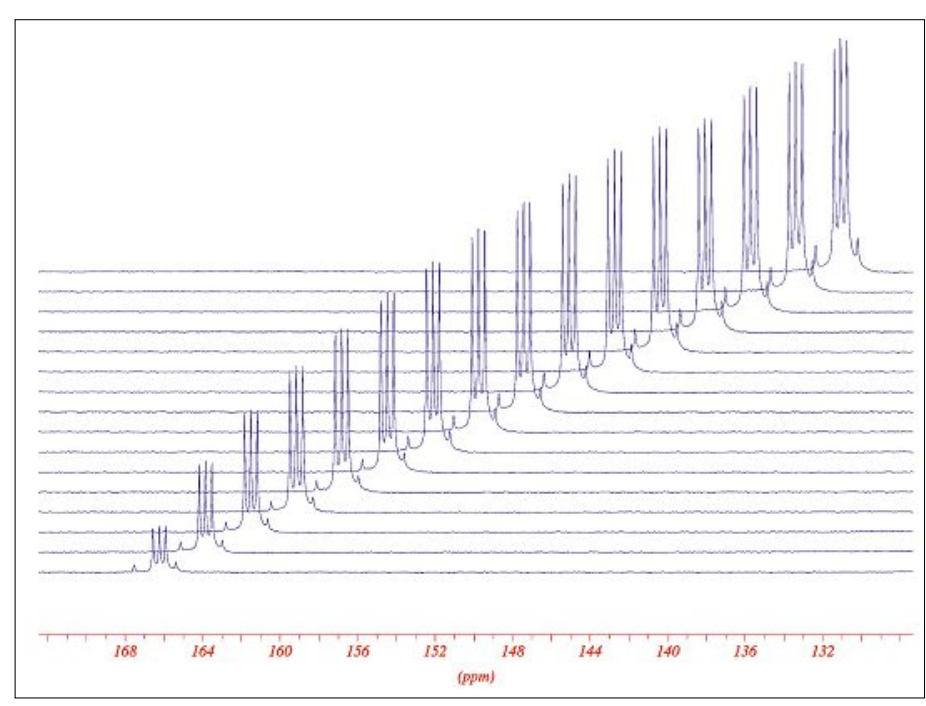

Fig. 6. ${ }^{13} \mathrm{C}$ NMR signals of DE्COD in the hydrogenation of $\mathrm{CO}_{2}$ into formic acid in $\mathrm{D}_{2} \mathrm{O}$. Reprinted from ref. [8] with permission from Nature Communications. 


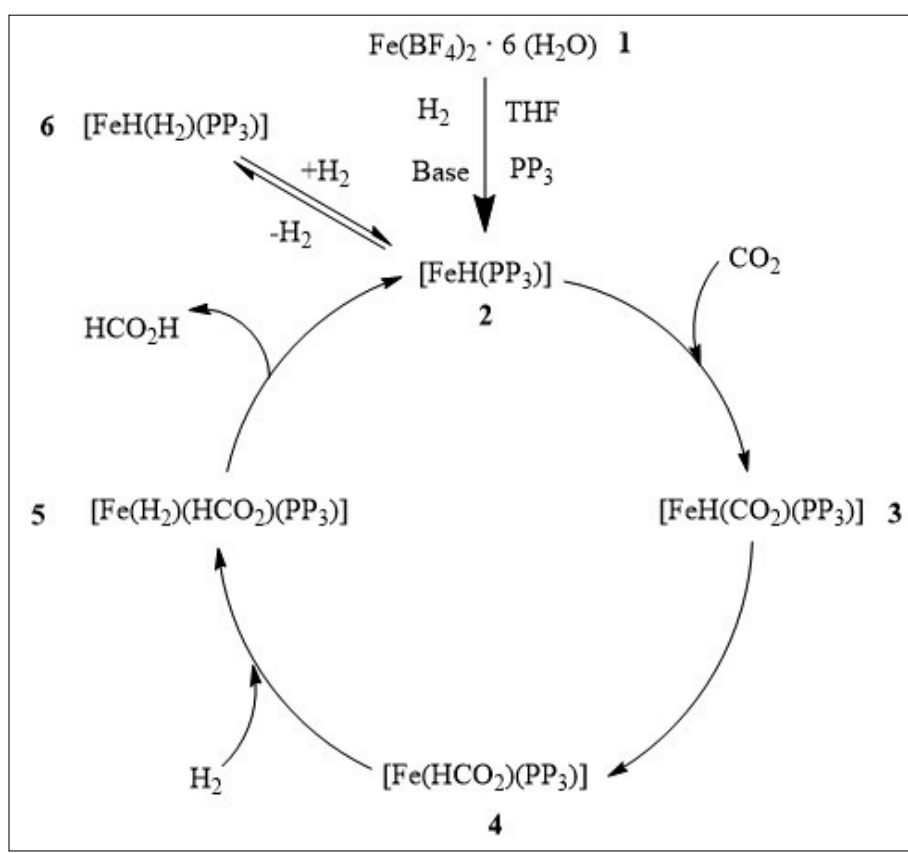

catalyst load) for hydrogenation. A catalytically crucial iron-hydrido-dihydrogen species was identified by high-pressure NMR studies. Furthermore, a tetradentate phosphorus ligand, which is easy obtainable in a one-pot reaction, was essential for successful catalysis. The synthesized complexes are stable at high temperatures $\left(>100{ }^{\circ} \mathrm{C}\right)$ and under air.

A novel synthesis route for formate salts, an important industrial precursor, was discovered by Beller's group in 2014. [31] In their study, a series of ruthenium pincer complexes was examined towards simultaneous methanol oxidation and bicarbonate reduction (hydrogenation), a green process without involving toxic gases $(\mathrm{CO})$ to synthesize formate salts with excellent TOF $>1300 \mathrm{~h}^{-1}$, TON up to 18000 , and total conversions over $90 \%$. Above all, this is the first report about combined catalytic dehydrogenation of methanol and reduction of $\mathrm{HCO}_{3}{ }^{-}$to a formate salt. The application of a commercially available pincer complex, HPNP ${ }^{\text {ph }}$ $\mathrm{Ru}$, resulted in a TON over 18000 (36 h) for the formation of $\mathrm{KOOCH}$.

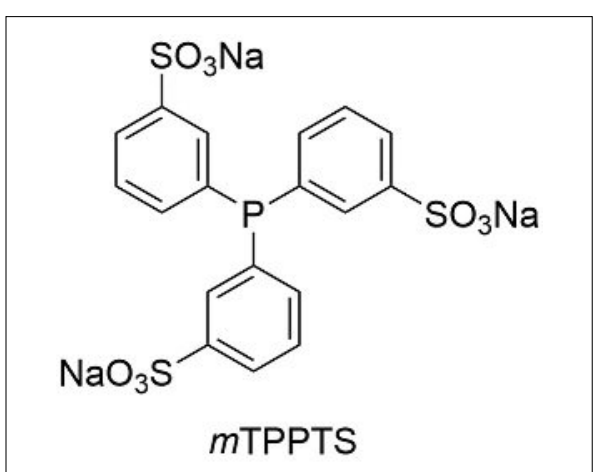

Fig. 8. Water-soluble $m$-triphenylphosphine trisulfonated ligand. $m$ TPPTS (250 mmol).
Fig. 7. Catalytic scheme for the hydrogenation of carbon dioxide with $\mathrm{Fe}\left(\mathrm{BF}_{4}\right)_{2} / \mathrm{PP}_{3}$ Reprinted from ref. [7] with permission from Angewandte Chemie International Edition.

The homogeneous catalyst $\left[\mathrm{RuCl}_{2}\right.$ (benzene)]2/dppe (dppe $=1,2$-bis (diphenylphosphino)ethane) is active in both the hydrogenation of carbon dioxide in basic media and the dehydrogenation of formic acid-triethylamine adducts to hydrogen and $\mathrm{CO}_{2}{ }^{[32]}$ The direction of the reaction can be reversed by changing the partial pressures of the corresponding gases. A low overall pressure (atmospheric pressure) facilitates the dehydrogenation of formic acid (discharging), whereas high hydrogen and $\mathrm{CO}_{2}$ pressures lead to the hydrogenation to formate (charging). The successful combination of both pathways is a fundamental requirement for operational hydrogen charge/discharge devices.

\section{Formic Acid Dehydrogenation}

Formic acid and its decomposition into $\mathrm{H}_{2}$ and $\mathrm{CO}_{2}$ is a sustainable way to store and produce hydrogen, alongside $\mathrm{CO}$ $\left(\mathrm{HCOOH} \rightarrow \mathrm{H}_{2}+\mathrm{CO}_{2}\right)$, if formic acid is synthetized by using 'green' energy/ hydrogen (see above). One liter of formic acid contains $53 \mathrm{~g}$ of $\mathrm{H}_{2}$, which corresponds to $4.4 \mathrm{wt} \%$, making it an elegant and interesting liquid as organic hydrogen carrier. However, formic acid exhibits a second decomposition pathway, dehydra- tion, producing water and $\mathrm{CO}(\mathrm{HCOOH} \rightarrow$ $\mathrm{H}_{2} \mathrm{O}+\mathrm{CO}$ ). As one of the goals is to use the produced hydrogen in PEM fuel cells to generate electricity, the later reaction should be avoided as $\mathrm{CO}$ is a poison for the membrane of such cells.

Back to 2006, our group was the first one to report the use of ruthenium complexes for selective formic acid cleavage with the idea of producing hydrogen. ${ }^{[33]}$ The decomposition of formic acid was carried out in aqueous solutions using hydrophilic ruthenium-based homogeneous catalysts, generated from the highly water-soluble ligand $m$-trisulfonated triphenylphosphine ( $m$ TPPTS, Fig. 8) with either $\left[\mathrm{Ru}\left(\mathrm{H}_{2} \mathrm{O}\right)_{6}\right]^{2+}$ or the commercially available $\mathrm{RuCl}_{3} \cdot 3 \mathrm{H}_{2} \mathrm{O}$.

Using sodium formate to activate the catalyst, $100 \%$ conversion of formic acid was reported, with generated $\mathrm{H}_{2}$ and $\mathrm{CO}_{2}$ pressure from 1 to 800 bar with no inhibition of the catalytic activity. Moreover, no traces of $\mathrm{CO}$ could be seen using FT-IR techniques (detection limit: 3 ppm). Using these catalysts, a continuous system was developed, allowing constant high-pressure hydrogen generation (Table 1).

In 2009, we detailed the mechanism of the aforementioned dehydrogenation. ${ }^{[34]}$ Using multinuclear NMR techniques, intermediate structures were elucidated and a complete reaction mechanism was proposed. It consists of two competitive cycles, explaining the catalytic behavior (fast activation period followed by high catalyst activity).

Later attempts were made to combine the advantages of heterogeneous systems with homogeneous catalysts. Immobilization of the highly active Ru(II)- $m$ TPPTS catalyst on ion exchange resins, polymers and zeolites was carried out.[35] Using ion exchange to bind the catalyst, the activity was the same as for the first catalytic cycle in the homogeneous catalytic system. However, recycling led to a decrease in the reaction rate, although the conversion stayed the same. Polymerized phosphine catalyst precursors were not effective, having a decreased reaction rate and yield. Regarding the immobilization on zeolites, there is a dependence on the type of the applied zeolite. Zeolites with low absorbing ability resulted in low reaction rates while stronger absorbents gave similar results to

Table 1. Formic acid consumption rates, hydrogen production rates, and turnover frequencies of the continuous system at 150 bar constant pressure.

\begin{tabular}{|r|c|c|c|}
\hline $\mathrm{T}\left[{ }^{\circ} \mathrm{C}\right]$ & $\mathrm{HCOOH}$ input $\left[\mathrm{mL} \cdot \mathrm{min}^{-1}\right]$ & $\mathrm{H}_{2}$ outflow $\left[\mathrm{mL} \cdot \mathrm{min}^{-1}\right]$ & $\mathrm{TOF}\left[\mathrm{h}^{-1}\right]$ \\
\hline 100 & $0.21 \pm 0.01$ & $140 \pm 10$ & $230 \pm 5$ \\
\hline 120 & $0.42 \pm 0.01$ & $290 \pm 10$ & $460 \pm 24$
\end{tabular}

$50 \mathrm{~mL}$ reactor, $12 \mathrm{~mL}$ initial solution of $\mathrm{HCOOH} / \mathrm{HCOONa}(9: 1,4 \mathrm{M}),\left[\mathrm{Ru}\left(\mathrm{H}_{2} \mathrm{O}\right)_{6}\right]$ (tos) $)_{2}(125 \mathrm{mmol})$, 
the aqueous homogeneous systems, even after 92 recycling experiments. However, according to the XRF spectra, when these solid catalysts were washed with water, the $\mathrm{Ru}-m$ TPPTS complex could be removed gradually, showing that the zeolites here were mainly acting as physical adsorbents. The catalyst immobilization on mesoporous silica was successful and led to a patent application. ${ }^{[36]}$

In 2010, the effect of the water-soluble sulfonated phosphine ligands on ruthenium-catalyzed generation of hydrogen from $\mathrm{HCOOH}$ was investigated.[37] Different phosphines were synthetized by changing substituents, thus varying the bulkiness, basicity, hydrophobicity. It was shown that the best ligands were $m$ TPPTS and $m$ TPPDS (triphenylphosphine, $m$-disulfonated) that offer a good compromise between steric effects and phosphine basicity, alongside with a good stability and an excellent solubility in water.

So far, viable results in our group were obtained using ruthenium-based catalysts, but the need for precious metal has inherent drawbacks. Due to its scarcity, it is relatively expensive; the large scale and industrial use could have limitations. With the idea of using a non-precious metal-based catalyst, a collaboration between our group and Beller's resulted in the development of an outstanding system, with TOF up to $9425 \mathrm{~h}^{-1}$ and TONs up to $92^{\prime} 000$, based on a $\left[\mathrm{Fe}\left(\mathrm{BF}_{4}\right)_{2}\right] \cdot 6 \mathrm{H}_{2} \mathrm{O}$ metal precursor with $\mathrm{PP}_{3}$ (Fig. 9) as ligand capable of selective formic acid dehydrogenation in propylene carbonate solution (Table 2). ${ }^{[38]}$

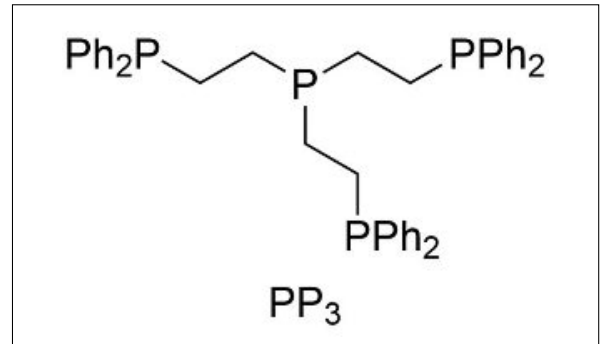

Fig. 9. Tris[2-(diphenylphosphino)ethyl]phosphine ligand.

The catalytic activity was tested for different precursors and with already activated catalyst.

It is to be noticed that the use of two equivalents of $\mathrm{PP}_{3}$ greatly enhances the catalytic activity. The chloride ion has a poisoning effect on the catalyst, as $\left[\mathrm{FeCl}\left(\mathrm{PP}_{3}\right)\right] \mathrm{BF}_{4}$ complex showed no activity in the dehydrogenation reaction. The same effect could be seen when adding excess $\mathrm{Cl}^{-}$into the reaction mixture. The use of four equivalents of ligand at $80{ }^{\circ} \mathrm{C}$ allowed continuous production of hydrogen with a TOF of $5400 \mathrm{~h}^{-1}$ over $16 \mathrm{~h}$. The activation energy, $\mathrm{E}_{\mathrm{A}}$, was determined

Table 2. Selective iron-catalyzed hydrogen evolution from formic acid using iron precursors. Reprinted fron ref. [38b] with permission from Science.

\begin{tabular}{c|c|c|c|c|c|}
\hline Entry & Catalyst & $\mathrm{V}_{2 \mathrm{~h}}[\mathrm{~mL}]$ & $\mathrm{V}_{3 \mathrm{~h}}[\mathrm{~mL}]$ & $\mathrm{TON}_{2 \mathrm{~h}}$ & $\mathrm{TON}_{3 \mathrm{~h}}$ \\
\hline 1 & {$\left[\mathrm{Fe}\left(\mathrm{BF}_{4}\right)_{2}\right] \cdot 6 \mathrm{H}_{2} \mathrm{O} / \mathrm{PP}_{3}$} & 146 & 215 & 562 & 825 \\
\hline 2 & {$\left[\mathrm{Fe}\left(\mathrm{BF}_{4}\right)_{2}\right] \cdot 6 \mathrm{H}_{2} \mathrm{O} / 2 \mathrm{PP}_{3}$} & 333 & 505 & 1279 & 1942 \\
\hline 3 & {$\left[\mathrm{FeH}\left(\mathrm{PP}_{3}\right)\right] \mathrm{BF}_{4}$} & 194 & 295 & 745 & 1135 \\
\hline 4 & {$\left[\mathrm{FeH}\left(\mathrm{PP}_{3}\right)\right] \mathrm{BF}_{4} / \mathrm{PP}_{3}$} & 319 & 500 & 1227 & 1923 \\
\hline 5 & {$\left[\mathrm{FeH}\left(\mathrm{H}_{2}\right)\left(\mathrm{PP}_{3}\right)\right] \mathrm{BF}_{4}$} & 189 & 294 & 727 & 1129 \\
\hline 6 & {$\left[\mathrm{FeH}\left(\mathrm{H}_{2}\right)\left(\mathrm{PP}_{3}\right)\right] \mathrm{BPh}_{4}$} & 174 & 264 & 670 & 1015 \\
\hline 7 & {$\left[\mathrm{FeCl}\left(\mathrm{PP}_{3}\right)\right] \mathrm{BF}_{4}$} & 0.4 & 0.4 & - & - \\
\hline
\end{tabular}

to give additional kinetic information, it was found to be equal to $77 \mathrm{~kJ} \cdot \mathrm{mol}^{-1}$ in propylene carbonate and $82 \mathrm{~kJ} \cdot \mathrm{mol}^{-1}$ in THF.

In 2011, the reaction of formate dehydrogenation was combined with the hydrogenation of bicarbonate (Eqn. (1)) to obtain a viable hydrogen storage charge/discharge device ('chemical hydrogen cylinder'), capable of storing and releasing hydrogen on demand. ${ }^{[39]}$ This process can be controlled by modifying the equilibrium position via the temperature and the hydrogen pressure change. By increasing the $\mathrm{H}_{2}$ pressure, bicarbonate will undergo hydrogenation and form formate; and, by releasing the $\mathrm{H}_{2}$ pressure, formate will decompose and produce hydrogen. Both reactions are catalyzed by the same [ $\left.\left\{\mathrm{RuCl}_{2}-(m \mathrm{TPPMS})_{2}\right\}_{2}\right]$ $+m$ TPPMS complex, without the need of isolating either the formate or bicarbonate to start a new cycle, in aqueous solution.

$$
\mathrm{HCO}_{3}^{-}+\mathrm{H}_{2} \rightleftharpoons \mathrm{HCOO}^{-}+\mathrm{H}_{2} \mathrm{O}
$$

The reversible hydrogen storage has been achieved using different conditions and catalysts. ${ }^{[19]}$ In order to come closer to the realization of a practical $\mathrm{H}_{2}$ storage-discharge device, the equilibrium position of formic acid/amine- $\mathrm{CO}_{2}$ systems has been examined as a function of pressure and temperature under isochoric conditions. ${ }^{[32]}$ It appears that high yields of formic acid dehydrogenation into $\mathrm{H}_{2}$ and $\mathrm{CO}_{2}$ are favored by low gas pressures and/or high temperatures and $\mathrm{H}_{2}$ uptake is possible at elevated $\mathrm{H}_{2} / \mathrm{CO}_{2}$ pressures. The development of systems capable of charging/discharging is of great interest, as it could be used for small and portable applications.

Recently we have evaluated and summarized the potential of the formic acid for hydrogen storage and delivery. ${ }^{[40]}$ The review widely explains the trends using both homogeneous and heterogeneous catalysts, explaining the advantages and the disadvantages of each method. Obviously heterogeneous catalysts are easier to recycle, but in general, homogeneous cata- lysts tend to be more active and selective, although the gap is closing. The alternative hydrogen storage possibilities were also reviewed, focusing on the different approaches, including both chemically or physically bound $\mathrm{H}_{2}$, comprising the use of formic acid. [41]

For a long period, only neutral and anionic ligands were used as catalyst precursors for the liberation of hydrogen from HCOOH. In 2013 we published the use of cationic phosphine precatalysts for formic acid dehydrogenation. ${ }^{[42]}$ To obtain such phosphines, ammoniomethyl substituents were introduced into the triarylphosphines. Several similar ligands were tested, varying in the charge (from $1+$ to $6+$ ) and in bulkiness. The best results were achieved with a 2+ ligand, charged twice on the same aryl group. Comparing the dehydrogenation reaction rates with these phosphines to the $m$ TPPTS under similar experimental conditions, the cationic ligands are more efficient. This could be due to the overall positive charges, which renders the environment cationic around the central metal atom and, therefore, leads to a faster coordination/migration of the negatively charged species $\left(\mathrm{HCOO}^{-}, \mathrm{HCO}_{3}^{-}\right.$and $\left.\mathrm{H}^{-}\right)$. However, it is more difficult to synthesize such cationic ligands, and they are less robust, being sensitive to oxygen.

In the case of pressurized reaction systems it is not easy to determine the concentration of dissolved species such as $\mathrm{HCOOH}, \mathrm{HCOONa}, \mathrm{CO}_{2}, \mathrm{Na}_{2} \mathrm{CO}_{3}$ and $\mathrm{NaHCO}_{3}$, as well as the $\mathrm{pH}$, in situ, under $\mathrm{H}_{2}$ and/or $\mathrm{CO}_{2}$ pressure. [43] It can be done by multinuclear NMR spectroscopy, as the chemical shift for ${ }^{13} \mathrm{C}$ and ${ }^{1} \mathrm{H}$ NMR are dependent on the $\mathrm{pH}$ of the solution and then with a calibration curve it is then possible to relate the $\mathrm{pH}$ to the chemical shift of the $\mathrm{H}$ and $\mathrm{C}$ atoms of the formic acid.

For the solute concentration, it was found that the integrals of formic acid, formate, carbonate, bicarbonate and carbon dioxide NMR signals are proportional to their concentrations if appropriate long relaxation delay times (D1) were chosen in the experiments. This tool has been proven valuable to investigate reaction kinetics 
and mechanisms in $\mathrm{H}_{2}$ storage/delivery with the carbon dioxide-formic acid systems under $\mathrm{H}_{2}$ and $\mathrm{CO}_{2}$ pressures (Fig. 10). $[43]$

In the meantime, research on $m$ TPPTS was still going on and the mechanism of the first 'fast' cycle for formic acid dehydrogenation catalyzed by $m$ TPPTS ruthenium complex was elucidated.[34,44] Using NMR techniques and time-resolved manometry, the dehydrogenation reaction was intensively studied and some key catalytic intermediates were identified. With those data, a rational cycle was pro-

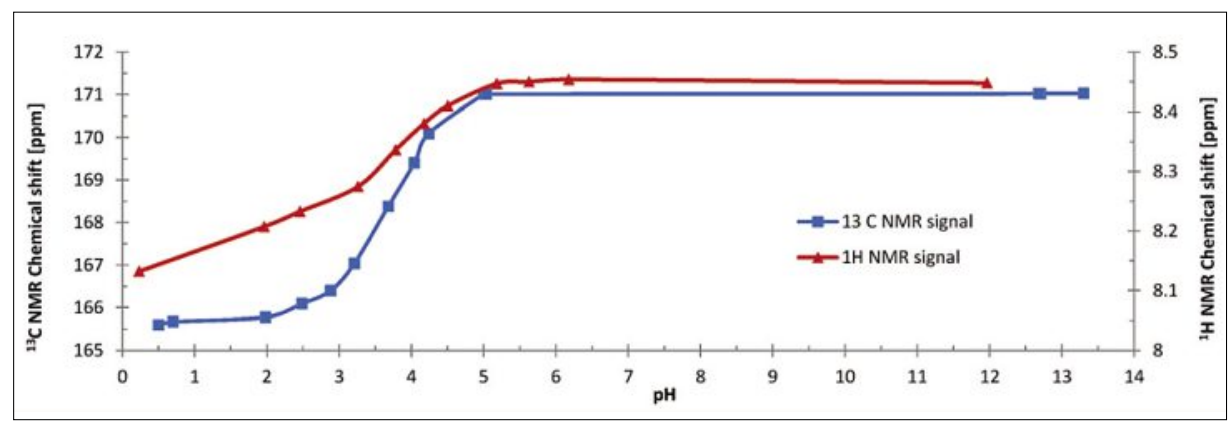

Fig. 10. Chemical shifts of the $\mathrm{HCOO} / / \mathrm{HCOOH}^{13} \mathrm{C}$ NMR doublet $\left(\mathrm{c}_{\text {total }}=0.1 \mathrm{M}\right)$ (blue squares, left axis) and ${ }^{1} \mathrm{H}$ NMR singlet $(\mathrm{c}=0.1 \mathrm{M})$ (red triangles, right axis) as a function of $\mathrm{pH}$. Reprinted from ref. [42] with permission from Dalton Transactions.

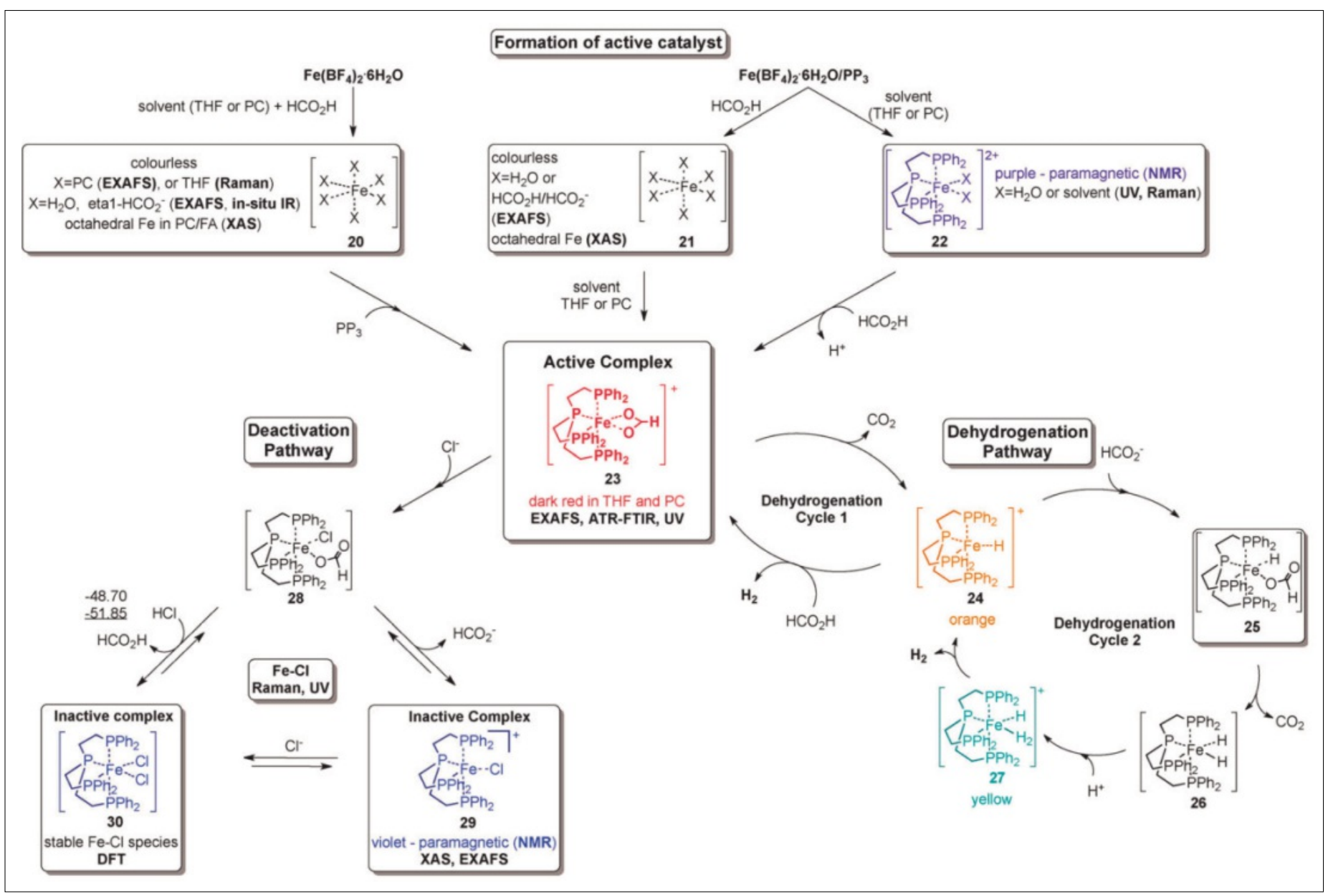

Fig. 11. Summary of the activation and deactivation pathways of the $\mathrm{Fe}\left(\mathrm{BF}_{4}\right)_{2} \cdot 6 \mathrm{H}_{2} \mathrm{O} / \mathrm{PP}_{3}$ catalyst system as well as proposed species formed based on the results of spectroscopic analyses. Reprinted from ref. [45] with permission from Chemistry - A European Journal.

posed, explaining the transition to the slow cycle.

The iron(II) based catalytic precursors were further investigated (Fig. 11). ${ }^{[44]}$ Optimization of the conditions (solvent, concentration, temperature) led to highly efficient catalyst systems with comparable activity to most known noble-metal catalysts used for this transformation. Spectroscopic investigations (IR, Raman, UV/Vis, $\mathrm{XAS}$ ) revealed the presence of different iron formate and hydride complexes. The iron $\kappa^{2}$-formate $\left[\mathrm{Fe}\left(\kappa^{2}-\mathrm{OOCH}\right)\left(\mathrm{PP}_{3}\right)\right]$ was observed for the first time under in situ re- action conditions and identified as the key active species for the catalysis. The deactivation of the catalyst by chloride could also be monitored easily by in situ IR spectroscopy and correlated with the evolution of $\mathrm{H}_{2}$ gas. Computational studies were also carried out to support the proposed reaction pathways.

\section{Acknowledgements}

The authors are grateful to the Swiss Competence Center for Energy Research (SCCER), the Swiss Commission for Technology and Innovation (CTI) and EPFL for financial support.
Received: August 12, 2015

[1] a) Q. Liu, L. Wu, R. Jackstell, M. Beller, Nat. Commun. 2015, 6, doi:10.1038/ncomms6933; b) T. G. Ostapowicz, M. Schmitz, M. Krystof, J. Klankermayer, W. Leitner, Angew. Chem. Int. Ed. 2013, 52, 12119.

[2] M. Aresta, A. Dibenedetto, A. Angelini, Chem. Rev. 2014, 114, 1709.

[3] M. Aresta, A. Dibenedetto, A. Angelini, in $A d v$. Inorg. Chem., Vol. 66, Eds. R. van Eldik, M. Aresta Academic Press, 2014, pp. 259-288.

[4] E. E. Benson, C. P. Kubiak, A. J. Sathrum, J. M. Smieja, Chem. Soc. Rev. 2009, 38, 89

[5] R. K. Clayton, 'Photosynthesis: Physical Mechanisms and Chemical Patterns', Cambridge University Press, 1980. 
[6] S. Fukuzumi, Eur. J. Inorg. Chem. 2008, 1351.

[7] C. Federsel, A. Boddien, R. Jackstell, R. Jennerjahn, P. J. Dyson, R. Scopelliti, G. Laurenczy, M. Beller, Angew. Chem. Int. Ed. 2010, 49, 9777.

[8] S. Moret, P. J. Dyson, G. Laurenczy, Nat. Commun. 2014, 5, 4017; doi:10.1038/ncomms5017.

[9] C. Federsel, R. Jackstell, A. Boddien, G. Laurenczy, M. Beller, ChemSusChem 2010, 3, 1048.

[10] G. Laurenczy, CHIMIA 2011, 65, 663.

[11] G. S. Bredig, R. Carter, His Majesty's Stationery Office, Pat. 9762, 1915.

[12] B. S. Jezowska-Trzebiatowska, J. Organomet. Chem. 1974, 80, C27.

[13] Y. Inoue, H. Izumida, Y. Sasaki, H. Hashimoto, Chem. Lett. 1976, 5, 863.

[14] E. Graf, W. Leitner, J. Chem. Soc., Chem. Commun. 1992, 623.

[15] R. Tanaka, M. Yamashita, K. Nozaki, J. Am. Chem. Soc. 2009, 131, 14168

[16] a) P. G. Jessop, F. Joó, C.-C. Tai, Coord. Chem. Rev. 2004, 248, 2425; b) W.-H. Wang, Y. Himeda, J. T. Muckerman, E. Fujita, in Adv. Inorg. Chem., Vol. 66, Eds. R. van Eldik, M. Aresta, Academic Press, 2014, pp. 189-222; c) A. Behr, K. Nowakowski, in Adv. Inorg. Chem., Vol. 66, Eds. R. van Eldik, M. Aresta Academic Press, 2014, pp. 223-258; d) Y. Himeda, W.-H. Wang, in 'New and Future Developments in Catalysis', Ed. S. L. Suib, Elsevier, Amsterdam, 2013, pp. 171-188.

[17] a) J. R. Khusnutdinova, J. A. Garg, D. Milstein, ACS Catalysis 2015, 5, 24162; b) P. Hu, Y. Diskin-Posner, Y. Ben-David, D. Milstein, ACS Catalysis 2014, 4, 2649; c) E. Balaraman, C. Gunanathan, J. Zhang, L. J. W. Shimon, D. Milstein, Nat. Chem. 2011, 3, 609.
[18] C. A. Huff, M. S. Sanford, J. Am. Chem. Soc. 2011, 133, 18122.

[19] A. Boddien, C. Federsel, P. Sponholz, D. Mellmann, R. Jackstell, H. Junge, G. Laurenczy, M. Beller, Energy Environ. Sci. 2012, 5, 8907.

[20] G. Laurenczy, F. Joó, L. Nádasdi, Inorg. Chem. 2000, 39, 5083

[21] G. Laurenczy, S. Jedner, E. Alessio, P. J. Dyson, Inorg. Chem. Commun. 2007, 10, 558.

[22] F. Joó, G. Laurenczy, P. Karády, J. Elek, L. Nádasdi, R. Roulet, Appl. Organomet. Chem. 2000, $14,857$.

[23] J. Elek, L. Nádasdi, G. Papp, G. Laurenczy, F. Joó, Appl. Catal. A 2003, 255, 59.

[24] H. Horváth, G. Laurenczy, Á. Kathó, J. Organomet. Chem. 2004, 689, 1036.

[25] T. J. Geldbach, G. Laurenczy, R. Scopelliti, P. J. Dyson, Organometallics 2005, 25, 733.

[26] S. S. Bosquain, A. Dorcier, P. J. Dyson, M. Erlandsson, L. Gonsalvi, G. Laurenczy, M. Peruzzini, Appl. Organomet. Chem. 2007, 21, 947.

[27] M. Erlandsson, V. R. Landaeta, L. Gonsalvi, M. Peruzzini, A. D. Phillips, P. J. Dyson, G. Laurenczy, Eur. J. Inorg. Chem. 2008, 620.

[28] G. Kovacs, L. Nadasdi, G. Laurenczy, F. Joó, Green Chem. 2003, 5, 213.

[29] a) Y. Inoue, Y. Sasaki, H. Hashimoto, J. Chem. Soc., Chem. Commun. 1975, 718; b) P. G. Jessop, Y. Hsiao, T. Ikariya, R. Noyori, J. Am. Chem. Soc. 1996, 118, 344.

[30] C. Ziebart, C. Federsel, P. Anbarasan, R. Jackstell, W. Baumann, A. Spannenberg, M. Beller, J. Am. Chem. Soc. 2012, 134, 20701.

[31] Q. Liu, L. Wu, S. Gülak, N. Rockstroh, R. Jackstell, M. Beller, Angew. Chem. Int. Ed. $\mathbf{2 0 1 4}, 53,7085$

[32] a) K. Sordakis, M. Beller, G. Laurenczy, ChemCatChem 2014, 6, 96; b) K. Sordakis,
A.Dalebrook, G. Laurenczy, ChemCatChem 2015, 7, 2332.

[33] a) G. Laurenczy, C. Fellay, P. Dyson, EP 1918247, 2006; b) C. Fellay, P. J. Dyson, G. Laurenczy, Angew. Chem. Int. Ed. 2008, 47, 3966.

[34] C. Fellay, N. Yan, P. J. Dyson, G. Laurenczy, Chem. Eur. J. 2009, 15, 3752.

[35] W. Gan, P. Dyson, G. Laurenczy, React. Kinet. Catal. Lett. 2009, 98, 205.

[36] W. Gan, J. P. Dyson, G. Laurenczy, PCT/CH 2013/000034, 2013.

[37] W. Gan, C. Fellay, P. J. Dyson, G. Laurenczy, J. Coord. Chem. 2010, 63, 2685.

[38] a) A. Boddien, B. Loges, F. Gärtner, C. Torborg, K. Fumino, H. Junge, R. Ludwig, M. Beller, J. Am. Chem. Soc. 2010, 132, 8924; b) A. Boddien, D. Mellmann, F. Gärtner, R. Jackstell, H. Junge, P. J. Dyson, G. Laurenczy, R. Ludwig, M. Beller, Science 2011, 333, 1733.

[39] G. Papp, J. Csorba, G. Laurenczy, F. Joó, Angew. Chem. Int. Ed. 2011, 50, 10433.

[40] M. Grasemann, G. Laurenczy, Energy Environ. Sci. 2012, 5, 8171 .

[41] A. F. Dalebrook, W. Gan, M. Grasemann, S. Moret, G. Laurenczy, Chem. Commun. 2013, 49, 8735 .

[42] W. Gan, D. J. M. Snelders, P. J. Dyson, G. Laurenczy, ChemCatChem 2013, 5, 1126.

[43] S. Moret, P. J. Dyson, G. Laurenczy, Dalton Trans. 2013, 42, 4353.

[44] A. Guerriero, H. Bricout, K. Sordakis, M. Peruzzini, E. Monflier, F. Hapiot, G. Laurenczy, L. Gonsalvi, ACS Catalysis 2014, 4, 3002.

[45] D. Mellmann, E. Barsch, M. Bauer, K. Grabow, A. Boddien, A. Kammer, P. Sponholz, U. Bentrup, R. Jackstell, H. Junge, G. Laurenczy, R. Ludwig, M. Beller, Chem. Eur. J. 2014, 20, 13589. 